\title{
Christie Palmerston: A reappraisal
}

\author{
R.M.W. Dixon
}

George Watson or Nyiyija (c1899-1991) was a magnificent indigenous scholar. He was well-versed in the language, legends, songs and customs of his own Dulgubarra Mamu people, from east of Innisfail in northern Queensland. He also had a useful knowledge of Waribarra Mamu, Jirrbal, Girramay and Ngajan (other dialects of what I call the Dyirbal language). George was one of my main teachers and my close friend from 1964 until his death. He recorded more than 20 texts and traditional stories, his own life story (in three long instalments), other historical narratives, an account of olden-day medicines and the like. He helped in the compilation of a fair-sized dictionary across ten dialects of Dyirbal, with equivalents supplied in the 'mother-in-law' avoidance style for most words from the everyday language style. Together with biologist Tony Irvine, we identified about 700 species of flora, and documented their uses. And George explained the grammar to me, and answered all of my questions. ${ }^{1}$

George's birth was the result of a casual encounter between his Mamu mother, Jarrabirrjan, and a white carrier, Arthur Watson. As George told the story, his mother had intended to kill him at birth (the fate of most 'half-caste' babies at that time and place) but her sister intervened and said she would bring George up with Polly, her own 'halfcaste' child. In fact George spent most of his early years with his mother's father, Nyaywi, who passed on the age-old inheritance of his people-how the world came to be as it is, the uses of important plants in the rain forest, and how one should behave in the Mamu way.

Over the years that I knew George he talked often of his grandfather Nyaywi and of the life they lived together around Jordan's Creek (a tributary of the South Johnstone River) in the jungle between Ravenshoe and Millaa Millaa, North Queensland. Early on, I enquired about George's grandmother, Nyaywi's wife. 'I never knew her', George replied, 'she was shot by Palmerston, before I was born. Palmerston used to come and shoot up a whole camp of blackfellows, those that didn't manage to run off into the scrub. He got my grandmother, had a intercourse with her, and then shot her dead'.

Christie Palmerston had been born about 1850 (place and parentage unknown). In 1869 he was charged with theft at Rockhampton and sentenced to jail for two years. In 1878 Palmerston was advertised as wanted by the Cairns police for an unspecified fel-

1. See the published grammar, Dixon (1972), and an informal account of doing linguistic fieldwork in the area in Dixon (1983). 
ony. On the positive side, he marked out tracks from the inland mineral fields to the coast-from the Hodgkinson Gold Fields to Port Douglas, and from Herberton to Mourilyan (near Innisfail, then called Geraldton). He styled himself 'Christie Palmerston, Explorer'. He has a reputation among the white population as an intrepid traveller, who 'opened up' the country. The Aborigines knew him as a bloody murderer.

George and I had long planned to document the story of Palmerston, but didn't get around to it until 15 July 1984. This was the last text George recorded and it was shorter than the others. He was about 85 years old at the time and drifted into senility just a couple of years later. Still, the essence of the story is crystal clear.

\section{Translation of the Palmerston story, as told by George Watson}

(The full text of Watson's story is included at the end of this article.)

Palmerston, he was going around with Dungginyu (called in English Paddy Onehand or Paddy Brooks). Dungginyu was leading him around (acting as a guide through the jungle); they came to our camp back here and saw my grandmother.

Palmerston raped her; soon after he shot her with a gun.

Then my grandfather (Nyaywi) returned, and called out 'Where's my wife from here?'

One of Nyaywi's friends replied, 'Palmerston killed here, down river there, at Garru (a place on the South Johnstone River)'.

'Oh yes?' Nyaywi replied.

'Yes. Dungginyu came with Palmerston, brought him here, and Palmerston frightened us away. But Palmerston grabbed her, and raped her over there, and shot her. It's a pity you didn't come back from your trip, earlier. You might have saved her. Shall we go and kill Dungginyu in revenge?'

Nyaywi answered, 'No. It doesn't matter, ignore him for the time being! Just let it go for now! She's dead'.

'Aren't you angry?'

'No.'

Nyawi's friend replied, 'Alright, but Dungginyu will keep on leading Palmerston around to rape and murder more of our people'.

Nyaywi insisted, 'Ignore him for a while! Later on we'll take revenge on Dungginyu, who was left behind by Palmerston when he returned to Innisfail. We will soon kill him in revenge. We will spit a curse at him, and as a result he will die'.

Nyaywi's friend said, 'Alright, but surely we should get together a posse to go for him, to kill Dungginyu'.

Nyaywi said, 'No, let him go for now. Ignore him for a while!'

The friend asked, 'Aren't you angry?'

'No. I'll stay here for a while longer. I'm not angry.'

'Will we be all squared up, talking to all of them?'

Nyaywi explained, 'Bye and bye I'll spit a curse at all of them. So that they (Dungginyu and his group) will be dead and gone'. 


\section{Comment}

This story epitomises Nyaywi's attitude to life and death. It was impossible to kill Palmerston since he lived in Innisfail, and when he ventured into the forest he was heavily armed and always alert. But Nyaywi's friend suggested that they should take their revenge on Palmerston's guide, Dungginyu - seek him out and kill him. Nyaywi knew that such a course would court trouble; Dungginyu's people would then be likely to undertake a revenge attack on Nyaywi's people. He preferred a different path. Nyaywi was an Aboriginal shaman (so called 'Aboriginal doctor') possessed of extrahuman powers. He planned to blow a curse at Dungginyu and his associates, as a result of which they would die inconspicuously.

Palmerston's diaries, and a number of documents associated with his career, have recently been published in a volume Christie Palmerston, Explorer, by Paul Savage. ${ }^{2}$ This is of mixed value. In one way it is most useful, making available the journals and other source material. ${ }^{3}$ In another way it is amazing, with Savage attempting to explain away or justify Palmerston's evil ways. Savage explains the necessity for Palmerston's frequent murder of Aborigines:

Towards any who resisted or rebelled against subordination to European requirements, or who stood in the way of European goals, utter ruthlessness was legitimate, even mandatory. In his diaries Palmerston disclosed actions and, in his Figaro interview, attitudes which would be outrageous in an Australian today. At that time they were not exceptional. ${ }^{4}$

He then comments:

Although none of these incidents can be regarded as exceptional, it is conceivable that they occurred with unusual frequency in Christie Palmerston's journeys: that he was especially prone to shoot. There is some evidence to support that conclusion. Such incidents occur in all his diaries.... On his return journey from Herberton to Mourilyan in 1882 Palmerston had repeated armed clashes with local Aborigines, whereas Douglas passed through the same area a few weeks earlier without one. $^{5}$

Palmerston used Aboriginal guides, who stayed with him partly out of fear. There is no doubt that he was trigger-happy, and would shoot on sight. Certainly he was attacked by Aboriginal groups, who wanted to kill him before he could kill any more of them. But-and this is the story of the whole take-over of Australia-the gun is mightier than the spear.

Palmerston's nastiness was by no means confined to his behaviour towards Aborigines. After he himself discovered gold on the Russell River in 1886 there came the inevitable rush. Palmerston then set up a protection racket, demanding one pound

2. Savage 1989. A second edition, Savage 1992, adds additional material but nothing that is relevant for this paper.

3. Although it must be noted that many of the 'explanatory' footnotes are misleading or erroneous. For instance, we are told on p. 132 that edible wood grubs are called "Jumbur" in the local language'; in fact the name is Jambun. On p. 131 Palmerston mentions 'the fullsounding voice of the scrub turkey' but a note says, "Dr Catton reports that the scrub turkey does not make any call'; in fact, the scrub turkey does make a sonorous grunting sound.

4. Savage 1989, p. 30; 1992, p. 33.

5. ibid. 
per head from each Chinese digger on the field, 'using armed Aborigines to back the demand, he permitted no-one to leave the field until he had paid up. He also forcibly prevented Chinese from bringing any meat on to the field in competition with the butchery he had established himself'. Savage the apologist states, 'If this was illegal extortion, it was remarkably modest in scale and legalistic in form'. One Chinese did bring a suit against Palmerston before the Police Magistrate in Innisfail; the magistrate found the charges proved. Savage explains this as due to the 'eccentric views' of the magistrate.

Palmerston's journals are probably accurate in describing his encounters with Aborigines. It is likely that George Watson's maternal grandmother was raped and murdered during the 'South Johnstone trip', 12-23 July 1886. An account of this was published in the Queensland Figaro in 1887 and is reprinted in Savage's book. ${ }^{6}$ Palmerston identifies two of his 'boys' (i.e. Aborigines) as 'Younganoo' and 'Nurrimpee'. It is probable that 'Younganoo' is Palmerston's attempt to transcribe the name Dungginyu (identified as his guide in George Watson's narrative). There were two encounters with Aborigines on this trip:

a) 20 July 1886 -'Here we were surprised by a hostile tribe of Aborigines that had been watching our movements the preceding day. Although they came upon us rather suddenly, a few shots soon dispersed them'.

b) 22 July 1886 - 'Later on, we topped a high spur, along the summit ran a large and freshly-used native path, going about east, which we followed till 3 p.m., when it led us straight into an Aborigines' camp. We saw the blacks before they observed us, and when I spoke to them they crashed through the jungle in the most terror-impressed disorder...'

Although we cannot be certain, it is most likely that 22 July 1886 was the date of the rape and summary murder of Nyaywi's wife. This would have been about 13 years before George Watson was born. And it was just on 98 years later that George set down the story on tape.

The entry on Palmerston in the Australian Dictionary of Biography ${ }^{7}$ includes the following: 'Respected as a consummate bushman, Palmerston was on unusually close terms with the Aboriginals whose allegiance he won by not interfering with their women and by his firmness and skill as a shot'. One part of this needs to be rewritten.

6. Savage 1989 , pp. $181-9 ; 1992$, pp. $190-8$.

7. Bolton 1984 


\section{The Palmerston story, told by George Watson in the Mamu dialect of Dyirbal}

(Watson's Mamu account of Palmerston's actions was recorded on 15 July 1984 at Boogan, near Innisfail, Queensland. ${ }^{8}$

1. Bamajin ${ }^{a} /$ balay bayi bayi-rri-nyu ${ }^{b}$ Dungginyu ${ }^{c}-n g u n j i n-d a /$ name THERE HE twist-REF-PAST name-GEN-LOC Palmerston, he was going around with Dungginyu.

2. Dungginyu bayi bagul munda-munda-lnga-nyu/ ngana-ngu name HE HIM-DAT REDUP-lead-APASS-PAST WE-GEN mija-gu bani-nyu/ yalu-ngarru/ ngaygu camp-DAT come-PAST TO.HERE MY gumburrin-an.gu bura-lnga-ygu/ mother's mother-DAT see-APASS-PURP

Dungginyu was leading him around (as a guide through the jungle); [they] came to our camp back here and saw my grandmother.

3. Banggul balan wadi-n/ gilu minba-li/ gama-nggu/ HE+ERG HER rape-PAST bye-and-bye shoot-PURP gun-INST He (Palmerston) raped her; soon after he shot her, with a gun.

4. Anyja ngagirrin ngurba-nyu nganba-lnga-ygu/ NEW TOPIC mother's.father return-PAST call.out-APASS-PURP Then [my] grandfather (Nyaywi) returned, and called out:

5. 'Wunyjan yangum ngaygu?'/ WHERE+FEM FROM.HERE MY

'Where's my [wife] from here?'

6. 'Bamajin-du minba-n/ balay-balbulu/ name-ERG shoot-PAST THERE-LONG.WAY.DOWNRIVER Garru-ngga'/ place-LOC

[One of Nyaywi's friends replied:] 'Palmerston killed her, down river there, at Garru (a place on the South Johnstone River).'

7. 'Ngayi?'/

yes

'Oh yes?' [Nyaywi replied].

8. 'Nga, Dungginyu-gu bani-ma-n yalu-mba-n/ yes name-ERG come-COM-PAST TO.HERE-TR.VB-PAST ngana-n.gu yarrnga-lnga-ygu / WE-DAT frighten away-APASS-PURP

'Yes, Dungginyu came with him, brought him here, and he frightened us away.

8. The following phonetic conventions are followed: $j$ for laminal stop, $n y$ for laminal nasal, $n g$ for dorso-velar nasal, $n . g$ for $n$ followed by $g, r$ for apical trill, $r$ for semi-retroflex rhotic continuant, / for the end of an intonation group.

Abbreviations used in examples are: APASS, antipassive; COM, comitative; DAT, dative; ERG, ergative; FEM, feminine; GEN, genitive; IMP, imperative; $\mathrm{INCH}$, inchoative (intransitive) verbaliser; INST, instrumental; LOC, locative; PURP, purposive; REDUP, reduplicated; REF, reflexive; REL, relative clause marker; TR.VB, transitive verbaliser. 
9. 'Ngana warrjila-bi-n jinggali-nyu/ yalgay-gabun-da

WE scattered-INCH-PAST run-PAST path-ANOTHER-LOC jinggali-nyu'/ run-PAST

'We all ran, scattering, all running in different directions.'

10. 'Banggul nyima-li/ anyja balay-bawal banggul balan HE-ERG grab-PURP THEN THERE-LONG.WAY HE-ERG HER wadi-n/ anyja minba-n/ rape-PAST THEN shoot-PAST

'But he grabbed her, and raped her over there, and shot her.'

11. 'Nginda gulu ngurba-yarra-nyu bani-nyu/ YOU NOT return-START-PAST come-PAST '[It's a pity] you didn't come back [from your trip, earlier, you might have saved her].

12. 'Ngurri ngana yanu-li balga-lnga-ygu ${ }^{\mathrm{e}}$ bagul?' / IN TURN WE go-PURP kill-APASS-PURP him-DAT 'Shall we go and kill him [Dungginyu] in revenge?'

13. 'Yimba/ miju-gani mugu-ban/ no take.no.notice of-KEEP.DOING-IMP NO MATIER-EMPHATIC mugu-ban jarra/ anyja NO MATI'ER-EMPHATIC let.go-IMP NEW.TOPIC dead-INCH-REL [Nyaywi answered:] 'No. It doesn't matter, ignore him for the time being! Just let it go for now! She's dead.'

14. 'Nginda bayi ${ }^{8}$ gulu guli-bi-ny?'/ YOU HE NOT ANGRY-INCH-NON.PAST 'Aren't you angry?'

15. 'Yimba'

no

'No.'

16. 'Ngayi/ Dungginyu-gu bayi munda-munda-li'/ alright name-ERG HIM REDUP-lead-PURP

[Nyaywi's friend replied:] 'Alright, but Dungginyu will keep on leading him [Palmerston] around [to rape and murder more of our people]'.

17. 'Miju-gani/ gilu bayi ngurri take.no.notice of-KEEP.DOING-IMP bye.and.bye HIM IN TURN nganaji/banggul bamajin-du galga-ngu/ WE HE+ERG name-ERG leave-REL

[Nyaywi insisted:] 'Ignore him for a while! Later on we'll take revenge on him (Dungginyu), who was left behind by Palmerston (when he returned to Innisfail).

18. 'Ngana bayi ngurri gilu guyi-ma-li/

WE HIM IN TURN bye.and.bye dead-TR.VB-PURP buybu-1i/ buga-bi-li' /

spit.a.curse.at-PURP dead-INCH-PURP

'We will soon kill him in revenge. We will spit a curse at him, and as a result he will die.' 
19. 'Ngu/ ngana margany-bi-li yanu-li bagul/

alright WE posse-INCH-PURP go-PURP HIM-DAT

dungginyu-nyan.gu balga-lnga-ygu'/

name-DAT kill-APASS-PURP

[Nyaywi's friend said:] 'Alright, [but surely] we should get together a posse to go for him, to kill Dungginyu.'

20. 'Yimba/janyja jarra/ miju-gani'/

no now let go-IMP take.no.notice of-KEEP.DOING-IMP

[Nyaywi said:] 'No, let him go for now. Ignore him for a while!'

21. 'Nginda bayi gulu guli ${ }^{\text {h }}$ waynyji-ny?'

YOU HE NOT angry rise.up-NON.PAST

[The friend asked:] 'Aren't you angry?'

22. 'Yimba/ngaja gilu jadanggu nyina-ygu/ ngaja gulu

no I bye.and.bye long period stay-PURP I NOT
guli waynyji-ny.'/
angry rise.up-NON.PAST
'No, I'll stay here a while longer. I'm not angry.'

23. 'Gilu-ma yalbara' nyina-ny/

bye.and.bye-QUESTION squared.up stay-NON.PAST

wurrba-nja-ny bagumanggan-an.gu'/

speak-TO.ALL-NON.PAST THEY-DAT

'Will [we] be all squared up, talking to all of them?'

24. 'Ngaja gilu bagu.manggan-an.gu buybu-lnga-ygu/

I bye.and.bye THEY-DAT spit.curse.at-APASS-PURP

'Bye and bye I'll spit a curse at all of them.

25. 'Munya-bi-li buga-bi-li'

finished-INCH-PURP rotten-INCH-PURP

'So that they [Dungginyu and his group] will be dead and gone.'

\section{Notes to the story}

a Bamajin is the name Palmerston, rendered into Mamu phonology.

$b$ The verb bayi-l means 'twist, stir round, wring'; here, with the reflexive suffix, bayi-rri-y means 'go around with', 'hang out with'.

c Dungginyu (also called Paddy One-hand or Paddy Brooks) came from the tribal group near Innisfail, which was hostile to Nyaywi's group.

$\mathrm{d}$ The verb yarrnga-l is 'frighten away' or 'chase away'. Its subject can be a flood, a fire, a fierce dog, or (as here) a gun-happy whiteman.

e The verb balga-1 means 'hit with a rigid implement, held in the hand' or 'kill' (a normal consequence of being hit in such a manner). See also line 19.

$f$ There are two ways of unambiguously saying 'kill' - through adding transitive verbaliser - ma-1 to noun guyi 'spirit' or to adjective buga 'rotten'. Similarly, 'die' involves adding inchoative verbaliser -bi-l to either gucyi or buga. See also lines 18 and 25.

$g$ Here (and in line 21) the intransitive subject phrase includes both nginda 'you' and the masculine determiner bayi (in other contexts, equivalent to 'he'), with the same reference.

h Adjective guli 'angry' and verb waynyji-l 'go up, rise up' here form an idiom 'get angry'.

i Adjective yalbara means 'all squared up after a dispute', 'freed of previous troubles', 'on a normal plane again'. 


\section{References}

Bolton, G.C. 1984, 'Christie Palmerston', in B. Nairn, G. Serle and R. Ward (eds) Australian Dictionary of Biography, vol. 95, Melbourne, pp. 395-6.

Dixon, R.M.W. 1972, The Dyirbal language of North Queensland, Cambridge.

Dixon, R.M.W. 1983, Searching for Aboriginal Languages: Memoirs of a Field worker, St Lucia (Queensland).

Savage, Paul (with maps and an essay by Alan Broughton) 1989, Christie Palmerston: Explorer, Townsville.

Savage, Paul (with maps and an essay by Alan Broughton) 1992, Christie Palmerston: Explorer, 2nd edition, revised and enlarged by B.J. Dalton, Townsville. 